\title{
PENGARUH PENGUNGKAPAN CORPORATE SOCIAL RESPONSIBILITY DAN LEVERAGE TERHADAP EARNING RESPONSE COEFFICIENT DENGAN GOOD CORPORATE GOVERNANNCE SEBAGAI VARIABEL MEDIASI
}

\author{
Arini Prihatiningrum \\ Fakultas Ekonomi \\ Universitas Sarjanawiyata Tamansiswa,Yogyakarta \\ e-mail : arininanlohy@gmail.com \\ Sri Ayem \\ Fakultas Ekonomi \\ Universitas Sarjanawiyata Tamansiswa, Yogyakarta \\ e-mail : sri.ayem@ustjogja.ac.id
}

\begin{abstract}
This study aims to analyze the disclosure of Corporate Social Responsibility (CSR) and Leverage on the Earnings Response Coefficient (ERC) by considering Good Corporate Governance as a mediating or intervening variable. The data used in this study are secondary data obtained from several sources. The subjects of this research are state-owned companies listed on the Indonesia Stock Exchange in 2016-2019. The sample of this study were 12 companies with a total of 48 data for 4 years from 2016 to 2019 which were selected by purposive sampling method. The analysis tool is the Classical Assumption Test and Path Analysis. This study found only four hypotheses were accepted, the other hypotheses were rejected. This study concludes that disclosure of Corporate Social Responsibility (CSR) has a positive effect on Good Corporate Governance (GCG), Leverage has a positive effect on Good Corporate Governance (GCG), Disclosure of Corporate Social Responsibility (CSR) has a positive effect on Earning Response Coefficient (ERC), Leverage. It has a positive effect on the Earning Response Coefficient (ERC), and Good Corporate Governance (GCG) is accepted to be added to the model as a mediating or intervening variable.
\end{abstract}

\begin{abstract}
ABSTRAK
Penelitian ini bertujuan untuk menganalisis pengungkapan Corporate Social Responsibility (CSR) dan Leverage terhadap Earnings Response Coefficient (ERC) dengan mempertimbangkan Good Corporate Governance sebagai variabel mediasi atau intervening. Data yang digunakan dalam penelitian ini adalah data sekunder yang diperoleh dari beberapa sumber. Subjek penelitian ini adalah perusahaan BUMN yang terdaftar di Bursa Efek Indonesia tahun 2016-2019. Sampel penelitian ini adalah 12 perusahaan dengan total 48 data selama 4 tahun dari tahun 2016 hingga 2019 yang dipilih dengan purposive sampling method. Alat analisis adalah Uji Asumsi Klasik dan Path Analysis. Penelitian ini menemukan hanya empat hipotesis yang diterima, hipotesis lainnya ditolak. Penelitian ini menyimpulkan bahwa Pengungkapan Corporate Social Responsibility (CSR) berpengaruh positif terhadap Good Corporate Governance (GCG), Leverage berpengaruh positif terhadap Good Corporate Governance (GCG), Pengungkapan Corporate Social Responsibility (CSR) berpengaruh positif terhadap Earning Response Coefficient (ERC), Leverage berpengaruh positif terhadap
\end{abstract}




\section{Buletin Ekonomi}

Earning Response Coefficient (ERC), dan Good Corporate Governance (GCG) diterima untuk ditambahkan dalam model sebagai variabel mediasi atau intervening.

\section{Kata Kunci : Corporate Social Responsibility (CSR), Leverage, Earning Response Coefficient (ERC), Good Corporate Governance (GCG).}

\section{PENDAHULUAN}

Salah satu informasi dalam laporan keuangan yang paling banyak mendapat perhatian dari para investor dan kreditor adalah laba.Laba merupakan indikator yang dapat digunakan untuk mengukur kinerja perusahaan. Informasi laba didalam laporan keuangan membuat investor akan memberikan reaksi yang berbeda-beda. Reaksi pasar ditunjukkan dengan adanya perubahan harga pasar (return saham) perusahaan tertentu yang terdapat perbedaan yang cukup besar antara return yang terjadi (actual return) dengan return harapan (expected return) pada saat pengumuman laba (Suwardjono,2005:491). Besaran yang menunjukkan hubungan antara laba dan return saham ini disebut dengan koefisien respon laba (Earning Response Coefficient-ERC).

Raksi pasar yang berbeda-beda terhadap informasi laba dapat disebabkan oleh berbagai hal. Dalam penelitian ini akan diuji salah satu faktor yang mungkin dapat mempengaruhi reaksi pasar terhadap informasi laba, yaitu pengungkapan Corporate Social Responsibility (CSR). Corporate Social Responsibility (CSR) merupakan konsep akuntansi baru yang muncul setelah adanya banyak kritik terhadap akuntansi konvensional yang dianggap tidak dapat mengakomodir kepentingan stakeholder. Stakeholder adalah orang atau kelompok yang memiliki kepentingan terhadap aktivitas perusahaan. CSR dikatakan berpijak pada triple bottom lines yaitu keuangan, sosial dan lingkungan. Selain mengungkapkan informasi keuangan, perusahaan juga diharapkan mengungkapkan informasi mengenai dampak sosial dan lingkungan hidup yang diakibatkan oleh aktivitas perusahaan.

Teori Agensi

Penelitian ini menggunakan teori agensi karena dalam kaitannya dengan good corporate governance, manajemen (agen) bertindak sebagai pembuat laporan keuangan yang nantinya akan dipertanggungjawabkan kepada pemilik perusahaan. Agen biasanya dianggap sebagai pihak yang ingin memaksimalkan dirinya tetapi ia tetap selalu berusaha untuk memenuhi kontrak sehingga laporan keuangan yang akan dihasilkan dapat berkualitas.

Teori Legitimasi

Teori legitimasi membahas tentang bagaimana perusahaan untuk meyakinkan bahwa aktivitas dan kinerjanya dapat diterima oleh masyarakat sekitar. Salah satu upaya perusahaan agar aktivitasnya diterima oleh masyarakat adalah dengan melaksanakan Corporate Social Responsibility. Dengan demikian terjadi keselarasan antara sistem perusahaan dan sistem nilai masyarakat yang dapat memberikan kelangsungan hidup suatu perusahaan.

Teori Stakeholder

Aktivitas yang dilakukan perusahaan tidak hanya untuk memaksimalkan laba saja, namun juga harus dapat memberikan keuntungan pada stakeholders. Stakeholders adalah kelompok yang berkepentingan, baik secara langsung maupun tidak langsung terhadap aktivitas perusahaan dan karena kelompok-kelompok tersebut mempengaruhi dan atau dipengaruhi oleh perusahaan.

Corporate Social Responsibility

Timbul berbagai persepsi mengenai pengertian dari tanggung jawab sosial setiap akademis atau institusi memiliki perdagangan yang berbeda, hampir seluruh akademis hingga institusi belum memiliki kesatuan pengertian yang baku mengenai tanggung jawab social ini. Pertanggungjawaban social perusahaan atau corporate social responsibility (CSR) adalah 


\section{Buletin Ekonomi}

mekanisme bagi suatu organisasi untuk secara sukarela mengintegrasikan perhatian terhadap lingkungan dan social dalam operasinya dan interaksinya dengan stakeholder yang melebihi tanggung jawab organisasi di bidang hukum.

Leverage

Rasio solvabilitas atau Leverage akan menggambarkan sejauh mana asset perusahaan dibiayai oleh hutang dibandingkan dengan modal sendiri. Leverage juga merupakan penaksir dari risiko yang melekat pada suatu perusahaan. Artinya, leverage yang besar menunjukkan risiko investasi yang besar pula, begitupun sebaliknya. Akan lebih baik apabila perusahaan mengusahakan sumber pendanaan internal terlebih dahulu daripada menggunakan sumber pendanaan eksternal. Semakin besar rasio solvabilitas menandakan aset dalam suatu perusahaan akan banyak dibiayai oleh hutang. Dengan demikian, dapat disimpulkan rasio leverage yang tinggi menyebabkan turunnya nilai perusahaaan. Investor tentu akan menyukai rasio leverage yang kecil karena laba perusahaan akan banyak digunakan dalam pembagian deviden dibanding angsuran hutang. Tingkat leverage dalam penelitian ini dijelaskan melalui Dept to Asset Ratio (DAR). Dept to Asset Ratio (DAR) adalah perbandingan antara total hutang dengan total asset yang dimiliki oleh perusahaan. Rasio ini dihitung hanya dengan membagi total hutang perusahaan dengan asset pemegang saham.

Earning Response Coefficient (ERC)

Suwardjono (2005:493) menyatakan bahwa koefisien respon laba (earning response coefficient) adalah kepekaan return saham terhadap setiap rupiah laba ataulaba kejutan (unexpected earning). Selisih antara laba harapan dan laba aktual disebut laba kejutan (unexpected earnings). Laba kejutan mempresentasi informasi yang belum tertangkap oleh pasar sehingga pasar akan bereaksi pada saat pengumuman laba. Itu berarti bahwa koefisien respon laba adalah suatu reaksi yang datang dari pengumuman laba perusahaan.

Good Corporate Governance (GCG)

Menurut agency theory, pihak manajemen sebagai agen lebih banyak mengetahui informasi maupun kondisi perusahaan dan dapat memanfaatkan kedudukannya untuk kepentingan pribadinya.Hal tersebut kemudian mendorong adanya suatu sistem pengawasan yang baik, biasa disebut dengan Good Corporate Governance (tata kelola yang baik). Dengan adanya GCG diharapkan mampu memberikan jaminan keamanan atas aset ataupun dana yang dimiliki perusahaan serta efisiensi penggunaannya. GCG memiliki mekanisme yang akan dibentuk oleh suatu perusahaan yang akan menerapkannya berupa komisaris independen, kepemilikan manajerial, kepemilikan institusional, dan komite audit yang akan mengawasi dan mengontrol manajemen sehingga dapat meningkatkan kinerja serta mengurangi konflik keagenan tersebut.

Pengaruh Pengungkapan Corporate Social Responsibility terhadap Good Corporate Governance

Dari aspek ekonomi, perusahaan harus bertujuan untuk mendapatkan keuntungan dan dari aspek sosial, perusahaan harus memberikan peranan secara langsung kepada masyarakat. Perusahaan tidak hanya dihadapkan pada tanggungjawab dalam perolehan keuntungan semata, tetapi juga harus memperhatikan tanggung jawab sosial dan lingkungannya.

Hasil penelitian Ahmad Roziq (2017) menunjukkan bahwa Pengungkapan Corporate Social Responsibility (CSR) berpengaruh positif terhadap Good Corporate Governance (GCG). Hasil dari penelitian tersebut berpengaruh signifikan secara marginal terhadap Good Corporate Governance (GCG). Namun berbeda dengan hasil penelitian yang dilakukan oleh Puspita Ayu (2016) menunjukkan Pengungkapan Corporate Social Responsibility (CSR) berpengaruh negative terhadap Good Corporate Governance (GCG). Hal ini terjadi karena masih sedikitnya perusahaan yang mengungkapkan CSR sehingga GCG tidak terkelola 


\section{Buletin Ekonomi}

dengan maksimal dan baik. Oleh sebab itu, berdasarkan uraian diatas, maka hipotesis dari penelitian ini adalah:

$\mathrm{H}_{1}$ : Pengungkapan CSR berpengaruh positif terhadap Good Corporate Governance.

Pengaruh Leverage terhadap Good Corporate Governance

Penerapan GCG dalam perusahaan diharapakan tingkat leverage mengalami penurunan. Semakin tinggi leverage menandakan bahwa adanya suatu tata kelola yang kurang didalam perusahaan. Karena itu diperlukan suatu pengendalian mengenai tata kelola perusahaan yang sering disebut dengan GCG. Pemegang hutang berkepentingan untuk melindungi investasinya dalam perusahaan dan akan secara aktif memantau seberapa besar tingkat leverage perusahaan tersebut. Perusahaan yang memiliki tingkat hutang yang tinggi dalam struktur modalnya akan cenderung menjadi sasaran pengawasan oleh kreditur. Kreditur sangat berkepentingan dengan praktik GCG dari debitur dan memiliki kekuasaan yang lebih besar dibandingkan pemegang saham untuk memaksa perusahaan meningkatkan kualitas GCG.

$\mathrm{H}_{2}$ : Leverage berpengaruh negatif terhadap Good Corporate Governance.

Pengaruh Pengungkapan Corporate Social Responsibility terhadap Earning Response Coefficient

Corporate Social Responsibility (CSR) adalah mekanisme bagi suatu organisasi untuk secara sukarela mengintegrasikan perhatian terhadap lingkungan dan social dalam operasinya dan interaksinya dengan stakeholder yang melebihi tanggungjawab organisasi di bidang hukum. Koefisien respon laba (earning response coefficient) merupakan koefisien yang diperoleh dari regresi antara proksi harga saham yaitu cumulative abnormal return (CAR) dan laba akuntansi yaitu unexpected earning (UE).

$\mathrm{H}_{3}$ : Pengungkapan Corporate Social Responsibility (CSR) berpengaruh positif terhadap

Earning Response Coefficient (ERC).

Pengaruh Leverage terhadap Earning Response Coefficient (ERC)

Leverage adalah penggunaan asset dan sumber dana oleh perusahaan yang memiliki biaya tetap dengan maksud agar meningkatkan keuntungan potensial pemegang saham. Financial leverage menunjukkan proporsi penggunaan utang untuk membiayai investasinya. Semakin tinggi tingkat leverage akan semakin tinggi tingkat risiko yang dihadapi serta semakin besar tingkat return atau penghasilan yang diharapkan. Koefisien Respon Laba didefinisikan sebagai efek setiap dolar unexpected earnings terhadap return saham, dan biasanya diukur dengan slopa koefisien dalam regresi abnormal returns saham dan unexpected earning.

$\mathrm{H}_{4}$ : Leverage berpengaruh negative terhadap Earning Response Coefficient (ERC).

Pengaruh Good Corporate Governance terhadap Earning Response Coefficient (ERC)

Penerapan GCG akan lebih berarti apabila dilakukan di negara berkembang. Indeks GCG menjadi salah satu faktor yang dapat menjelaskan nilai pasar. Secara empiris GCG indeks tidak berpengaruh terhadap ERC. Hal ini mengindikasikan bahwa GCG yang sudah dipublikasikan tidak cukup mendapatkan respon oleh publik terutama bagi investor. Dengan adanya mekanisme GCG yang efektif dapat meningkatkan nilai perusahaan. Semakin tinggi proporsi hutang, maka semakin besar tingkat risiko ekuitas karena kreditor harus dipenuhi sebelum pemilik dalam kebangkrutan.

$\mathrm{H}_{5}$ : Good Corporate Governance (GCG) berpengaruh positif terhadap Earning Response Coefficient (ERC).

Pengaruh pengungkapan Corporate Social Responsibility (CSR) terhadap Earning Response Coefficient (ERC) yang dimediasi Good Corporate Governance (GCG) 


\section{Buletin Ekonomi}

Tujuan penerapan GCG adalah untuk membangun citra perusahaan dan memenuhi tanggungjawab kepada pemegang saham, masyarakat serta kesejahteraan karyawan. Untuk menerapkan GCG perusahaan memenuhi tanggungjawab sosial kepada masyarakat dan pemegang saham. Tanggungjawab sosial atau lebih dikenal dengan dengan CSR dapat didefinisikan sebagai tanggungjawab moral suatu perusahaan kepada para pemegang saham, terutama komunitas atau masyarakat disekitar wilayah kerja dan operasinya. Suatu perusahaan dapat dikatakan bertanggungjawab secara sosial, ketika manajemennya memiliki visi atas kinerja operasional yang tidak hanya merealisasikan keuntungan, akan tetapi dapat meningkatkan kesejahteraan masyarakat atau lingkungan sosialnya.

$\mathrm{H}_{6}$ : Good Corporate Governance (GCG) mampu memediasi Pengungkapan Corporate Social Responsibility (CSR) terhadap Earning Response Coefficient (ERC)

Pengaruh Leverage terhadap Earning Response Coefficient (ERC) yang dimediasi Good Corporate Governance (GCG)

Leverage menunjukkan sejauh mana perusahaan dibiayai oleh hutang. Untuk leverage dapat dihitung dengan debt to total assets ratio (DAR) dan debt to total equity ratio (DER). Leverage mampu mengungkapkan suatu pengendalian eksternal dari GCG. Penerapan GCG dalam perusahaan diharapkan dapat menurunkan tingkat leverage maka resiko yang akan dihadapi perusahaan akan semakin besar. Hal ini menandakan bahwa adanya suatu tata kelola yang salah didalam perusahaan. Penerapan GCG akan lebih berarti apabila dilakukan dinegara berkembang.

$\mathrm{H}_{7}$ : Good Corporate Governance (GCG) mampu memediasi Leverage terhadap Earning Response Coefficient (ERC)

\section{METODE}

Data yang digunakan dalam penelitian ini adalah data sekunder yang diperoleh melalui beberapa sumber. Penelitian ini dilakukan dengan mengambil data laporan keuangan, laporan tahunan, nilai pasar, nilai buku ekuitas, return saham, harga penutupan saham, indeks harga saham gabungan, dan survey yang dilakukan oleh IICG pada perusahaan BUMN yang terdaftar di Bursa Efek Indonesia. Data sampel yang diambil sebanyak 12 perusahaan dengan total data 48 selama 4 tahun yang menerbitkan annual report pada tahun 2016 sampai dengan 2019. Data atas laporan keuangan tahunan tersebut dapat diperoleh melalui situs resmi Bursa Efek Indonesia dan data atas return saham, harga penutupan saham serta indeks harga saham tersebut dapat diperoleh melalui situs resmi duniainvestasi.com

Variabel Dependen

Variabel dependen yang pertama adalah Earning Response Coefficient (ERC).ERC adalah koefisien $(\beta)$ yang diperoleh dari regresi antara Cumulative Abnormal Return (CAR) dan Unexpected Earnings (UE). Dengan demikian, untuk menghitung besarnya ERC untuk masing-masing perusahaan adalah akumulasi abnormal return dari masing-masing perusahaan selama periode 3 hari sebelum tanggal publikasi annual report , 1 hari tanggal publikasi annual report, dan 3 hari sesudah tanggal publikasi. Abnormal return dihitung dengan rumus sebagai berikut: 


$$
\begin{gathered}
\mathrm{R}_{\mathrm{it}}=\frac{\mathrm{P}_{\mathrm{it}}-\mathrm{P}_{\mathrm{it}-1}}{\mathrm{P}_{\mathrm{it}-1}} \\
\mathrm{R}_{\mathrm{mt}}=\frac{\mathrm{IS} \mathrm{S}_{\mathrm{it}}-\mathrm{I} \mathrm{S}_{\mathrm{it}-1}}{I \mathrm{I}_{\mathrm{it}-1}} \\
\quad \mathrm{AR}_{\mathrm{it}}=\mathrm{R}_{\mathrm{it}}-\mathrm{R}_{\mathrm{mt}}
\end{gathered}
$$

Keterangan:

$\mathrm{AR}_{\text {it }} \quad$ : Abnormal Return untuk perusahaan i pada hari ke-t

$\mathrm{R}_{\mathrm{it}} \quad$ : Return harian perusahaan i pada hari ke-t

$\mathrm{R}_{\mathrm{mt}} \quad$ : Return indeks pasar pada hari ke-t

$P_{i t} \quad$ : Harga Saham perusahaan i pada waktu t

$\mathrm{P}_{\mathrm{it-1}} \quad$ : Harga Saham perusahaan i pada waktu t-1

IS $_{\text {it }} \quad$ : Indeks Sektoral pada waktu t

IS $\mathrm{it}_{\mathrm{it}-1} \quad$ : Indeks Sektoral pada waktu t-1

UE untuk masing-masing perusahaan dihitung dengan cara laba akuntansi setelah pajak dikurangi dengan laba akuntansi setelah pajak tahun sebelumnya, dan dibagi dengan laba akuntansi setelah pajak tahun sebelumnya.

\section{$\underline{\text { Laba Akuntansi Setelah Pajak - Laba Akuntansi Setelah Pajak Tahun }}$ F t-1 \\ Laba Akuntansi Setelah Pajak Tahun t-1}

Variabel Independen

Variabel independen pertama dari penelitian ini adalah Corporate Sosial Responsibility (CSR) yang diukur dengan Corporate Sosial Responsibility Index (CSRI). Mengacu pada penelitian terdahulu, maka pengukuran variabel Corporate Sosial Responsibility Index (CSRI) menggunakan content analysis yang mengukur variety dari Corporate SosialResponsibilityIndex (CSRI). Instrumen pengukuran CSRI yang akan digunakan dalam penelitianini berdasarkaninstrument Global Reporting Initiative (GRI) Index G4 and Global Compact Indicators. Pendekatan untuk menghitung Corporate Sosial Responsibility Index (CSRI) pada dasarnya menggunakan pendekatan dikotomi yaitu item Corporate Sosial Responsibility (CSR) dalam instrument penelitian diberi nilai 1 jika diungkapkan, dan nilai 0 jika tidak diungkapkan.

$$
\operatorname{CSRI}_{\mathrm{j}}=\frac{\sum \mathrm{X}_{\mathrm{ij}}}{\mathrm{n}_{\mathrm{j}}}
$$

Keterangan:

$\mathrm{CSRI}_{\mathrm{j}}$ : Corporate social responsibility disclosure indeks perisahaan $\mathrm{j}$

$\mathrm{n}_{\mathrm{j}} \quad$ : Jumlah item untuk perusahaan $\mathrm{j}, \mathrm{n}_{\mathrm{j}} \leq 91$

$\sum \mathrm{X}_{\mathrm{ij}} \quad$ : variabel dummy, 1 :jika item i diungkapkan, dan 0: jika item itidak diungkapkan. 


\section{Buletin Ekonomi}

Variabel independen kedua dari penelitian ini adalah leverage. Biasanya penggunaan rasio leverage dengan tujuan perusahaan. Artinya perusahaan dapat menggunakan rasio leverage secara keseluruhan atau sebagian dari masing-masing jenis rasio leverage yang ada. Jenis-jenis rasio leverage antara lain:

1. Debt To Equity Ratio (DER)

2. Debt To Asset Ratio (DAR)

3. Times Interest Earned Ratio (TIE)

4. Long Term Debt To Equity Ratio (LTDER)

Pada penelitian ini, penulis berfokus pada Debt To Asset Ratio (DAR) dalam menghitung rasio leverage. Debt To Asset Ratio (DAR), merupakan rasio utang yang digunakan untuk mengukur perbandingan antara total utang dengan total aset yaitu sebagai berikut:

DAR $=\frac{\text { Total Debt }}{\text { Total Asset }}$

Perusahaan dengan leverage yang tinggi menyebabkan investor kurang percaya pada laba yang di umumkan oleh perusahaan. Perusahaan dengan leverage yang tinggi menghadapi risiko rugi yang lebih tinggi di waktu tertentu, tetapi tingkat pengembalian yang diharapkan juga lebih tinggi. Reaksi pasar lebih rendah terhadap informasi laba perusahaan yang memiliki tingkat leverage yang tinggi. Semakin tinggi leverage suatu perusahaan maka akan semakin rendah Eraning Response Coefficient (ERC).

Variabel Mediasi

Variabel mediator atau mediasi dari penelitian ini adalah Good Corporate Governace (GCG) atau tata kelola perusahaan yang baik.Variabel ini diwakili oleh peringkat dalam Good Governace Perception Index yang dikeluarkan IICG (Indonesian Institute for Corporate Governace) dan majalah SWA sebagai media publikasi.Variabel ini menggunakan skala rating. Dalam persamaan, variabel ini disimbolkan CGPI. Indeks yang digunakan untuk memberikan skor berupa angka mulai 0-100.Jika perusahaan memiliki skor mendekati 100 maka perusahaan tersebut semakin baik dalam menerapkan Good Corporate Governace (GCG).

Teknik Analisis Data

Teknik analisis data yang digunakan dalam penelitian ini adalah uji asumsi klasik (uji normalitas, uji heterokedastisitas, uji multikolinieritas dan uji autokorelasi), uji hipotesis (uji statistik t dan uji statistik f) dan Analisis jalur (Path Analysis).

\section{ANALISIS DAN PEMBAHASAN}

Tahapan dalam pengujian regresi harus memenuhi beberapa uji asumsi klasik yaitu meliputi: uji normalitas, uji multikolinearitas, uji heteroskedastisitas dan uji autokorelasi yang secara rinci dijelaskan sebagai berikut:

Uji normalitas bertujuan untuk menguji apakah data berkelanjutan berdistribusi normal atau tidak. Dalam hal ini uji normalitas data dilakukan dengan pendekatan kolmogorov-smirnov. Uji kolmogorov-smirnov adalah salah satu uji statistik nonparametrik yang digunakan untuk mengetahui distribusi data yang digunakan dalam penelitian berdistribusi normal atau tidak. Pengujian normal atau tidaknya data dilakukan dengan melihat nilai signifikansi. Apabila nilai signifikansi (Sig.) lebih besar dari 0,05, maka data penelitian berdistribusi normal. Sebaliknya, jika nilai signifikansi (Sig.) lebih kecil dari 0,05 


\section{Buletin Ekonomi}

maka data penelitian tidak berdistribusi normal. Berikut hasil uji kolmogorov-smirnov. Hasil normalitas disajikan pada tabel berikut:

Tabel 1

Uji Kolmogorov-Smirnov

\begin{tabular}{llr}
\hline \multicolumn{2}{c}{ One-Sample Kolmogorov-Smirnov Test } \\
\hline & & $\begin{array}{c}\text { Unstandardi } \\
\text { zed } \\
\text { Residual }\end{array}$ \\
$\mathbf{N}$ & & 48 \\
Normal Parameters & Mean & .0000000 \\
& Std. Deviation & .03217194 \\
Most Extreme & Absolute & .111 \\
Differences & Positive & .111 \\
& Negative & -.055 \\
Kolmogorov-Smirnov Z & .769 \\
Asymp. Sig. (2-tailed) & .596
\end{tabular}

a. Test distribution is Normal.

(Sumber: Output SPSS 16.0, data sekunder yang diolah 2020)

Berdasarkan tabel 1 menunjukan bahwa nilai signifikan lebih besar dari 0,05 yaitu 0,596 sedangkan nilai kolmogorov-smirnov test yaitu sebesar 0,769 lebih besar dari 0,05, sehingga dalam uji normalitas ini dapat dikatakan bahwa data berdistribusi secara normal.

Uji multikolonieritas bertujuan untuk menguji apakah dalam model regresi terdapat korelasi antar variabel bebas. Model regresi yang baik seharusnya tidak terjadi korelasi diantara variabel bebas. Deteksi multikolonieritas dapat dilakukan dengan menganalisis matriks korelasi antar variabel independen dan dengan melihat nilai tolerance dan lawannya VIF. Adapun hasil uji multikolonieritas dengan menggunakan matriks korelasi sebagai berikut:

\section{Tabel 2}

Uji Multikolonieritas

\begin{tabular}{|c|c|c|c|c|c|c|}
\hline \multirow{2}{*}{\multicolumn{2}{|c|}{ Model }} & \multicolumn{3}{|c|}{ Coefficients $^{\mathbf{a}}$} & \multirow{2}{*}{\multicolumn{2}{|c|}{$\begin{array}{c}\text { Collinearity } \\
\text { Statistics }\end{array}$}} \\
\hline & & \multicolumn{2}{|c|}{$\begin{array}{l}\text { Unstandardized } \\
\text { Coefficients }\end{array}$} & \multirow{3}{*}{$\begin{array}{c}\text { Standardized } \\
\text { Coefficients } \\
\text { Beta }\end{array}$} & & \\
\hline \multirow{5}{*}{1} & & $\mathrm{~B}$ & $\begin{array}{l}\text { Std. } \\
\text { Error }\end{array}$ & & $\begin{array}{c}\text { Toleranc } \\
\mathrm{e}\end{array}$ & VIF \\
\hline & (Constant) & 1.900 & .078 & & & \\
\hline & CSR & .203 & .085 & .230 & .780 & $\begin{array}{c}1.28 \\
2\end{array}$ \\
\hline & Leverage & .069 & .030 & .223 & .753 & $\begin{array}{c}1.32 \\
7\end{array}$ \\
\hline & GCG & -.009 & .001 & -.863 & .916 & $\begin{array}{c}1.09 \\
2\end{array}$ \\
\hline
\end{tabular}

(Sumber: Output SPSS 16.0, data sekunder yang diolah 2020) 


\section{Buletin Ekonomi}

Berdasarkan hasil uji multikolinearitas pada tebel 2 diketahui nilai tolerance lebih besar dari $>0,10$ dan nilai variance linflation factor (VIF) lebih kecil dari < 10,00 maka dari itu, disimpulkan bahwa variabel tersebut tidak terjadi multikolinearitas.

Uji heteroskedastisitas bertujuan untuk mengetahui apakah terjadi penyimpangan model karena varian gangguan berbeda antara suatu observasi ke observasi lain. Untuk mendeteksi adanya gejala heteroskedastisitas dalam model persamaan regresi dapat menggunakan gambar model scatterplot atau uji glejser dengan program SPSS. Dalam hal ini peneliti menggunakan uji glejser. Pengujian glejser dilakukan dengan cara meregresikan variabel independen (bebas) dengan nilai absolut residualnya. Apabila nilai signifikansi (sig.) antara variabel independen dengan absolut residual lebih dari 0,05 ,maka tidak terjadi gejala heteroskedastisitas. Hasil pengujian heteroskedastisitas dapat ditunjukkan pada tabel berikut:

Tabel 3

Uji Heteroskedastisitas

\begin{tabular}{|c|c|c|c|c|c|c|}
\hline \multicolumn{7}{|c|}{ Coefficients $^{\mathbf{a}}$} \\
\hline \multirow{2}{*}{\multicolumn{2}{|c|}{ Model }} & $\begin{array}{r}\text { Unst } \\
\mathrm{Co}\end{array}$ & $\begin{array}{l}\text { Irdized } \\
\text { ients }\end{array}$ & $\begin{array}{c}\text { Standardize } \\
\mathrm{d} \\
\text { Coefficients }\end{array}$ & $\mathrm{t}$ & Sig. \\
\hline & & B & Std. Error & Beta & & \\
\hline \multirow[t]{4}{*}{1} & (Constant & -.015 & .048 & & -.306 & .761 \\
\hline & CSR & .018 & .052 & .058 & .346 & .731 \\
\hline & Leverage & .023 & .019 & .212 & 1.249 & .218 \\
\hline & $\mathrm{GCG}$ & .000 & .001 & .063 & .412 & .683 \\
\hline \multicolumn{7}{|c|}{ a. Dependent Variable: Abs_Res } \\
\hline
\end{tabular}

(Sumber: Output SPSS 16.0, data sekunder yang diolah 2020)

Berdasarkan uji heteroskedastisitas tabel 3 dapat diketahui nilai (Sig) pada ketiga variabel lebih besar dari 0,05 maka dapat disimpulkan bahwa tidak terjadi gejala heteroskedastisitas.

Pengujian ada atau tidaknya autokorelasi dilakukan dengan menggunakan metode Durbin-Watson. Adapun cara mendeteksi terjadi autokorelasi dalam model analisis regresi dengan menggunakan Durbin-Watson dapat dijelaskan sebagai berikut:

\section{Tabel 4}

Uji Autokorelasi

\begin{tabular}{lccccc}
\hline \multicolumn{5}{c}{ Model Summary $^{\mathbf{b}}$} \\
\hline Model & $\mathrm{R}$ & $\mathrm{R}$ & $\begin{array}{c}\text { Adjusted R } \\
\text { Square }\end{array}$ & $\begin{array}{c}\text { Std. Error of } \\
\text { the Estimate }\end{array}$ & $\begin{array}{c}\text { Durbin- } \\
\text { Watson }\end{array}$ \\
\hline $\mathbf{1}$ & $.170^{\mathrm{a}}$ & .029 & -.037 & .267489 & 1.742
\end{tabular}

\section{a. Predictors: (Constant), GCG, CSR, Leverage \\ b. Dependent Variable: ERC}

(Sumber: Output SPSS 16.0, data sekunder yang diolah 2020)

Dengan nilai tabel pada tingkat signifikansi 5\%, jumlah sampel 48 (n) dan jumlah variabel independen $2(\mathrm{k}=2)$. Nilai Durbin-Watson dari hasil analisis regresi sebesar 1,742 


\section{Buletin Ekonomi}

dapat dilihat pada tabel 4 diatas dengan demikian nilai Durbin-Watson tersebut berada pada interval 1,623 sampai dengan 2,378 $(1,623<1,742<2,378)$, sehingga dapat disimpulkan bahwa tidak terjadi gejala autokorelasi.

\section{Uji Statistik t}

Uji t digunakan untuk mengetahui pengaruh secara parsial variabel bebas terhadap variabel terikat. Pengujian ini yaitu dengan membandingkan nilai probabilitas atau p-value (sig-t) dengan taraf signifikansi 0,05. Jika nilai p-value lebih kecil dari 0,05 maka Ha diterima, dan sebaliknya jika p-value lebih besar dari 0,05 maka Ha ditolak. Hasil dapat dilihat pada tabel berikut ini:

\section{Tabel 5}

\section{Hasil Uji Signifikansi Parameter Individual}

\begin{tabular}{|c|c|c|c|c|c|c|}
\hline & & & Coefficie & & & \\
\hline & & $\begin{array}{r}\text { Unst } \\
\text { Co }\end{array}$ & $\begin{array}{l}\text { ardized } \\
\text { ients }\end{array}$ & $\begin{array}{c}\text { Standardize } \\
\mathrm{d}\end{array}$ & $\mathrm{t}$ & Sig. \\
\hline & & B & Std. Error & Beta & & \\
\hline 1 & (Constant & 1.900 & .078 & & 24.422 & .000 \\
\hline & CSR & .203 & .085 & .230 & 2.400 & .021 \\
\hline & Leverage & .069 & .030 & .223 & 2.290 & .027 \\
\hline & $\mathrm{GCG}$ & -.009 & .001 & -.863 & -9.762 & .000 \\
\hline
\end{tabular}

\section{a. Dependent Variable:}

ERC

Sumber: Output SPSS 16.0, data sekunder yang diolah 2020

Hasil uji t diatas dapat disimpulkan bahwa pada variabel Corporate Social Responsibility index $\mathrm{CCSRI}\left(\mathrm{X}_{1}\right)$ seperti pada tabel 5 diatas diperoleh t hitung sebesar 2,400 dengan probabilitas sebesar 0,021 yang nilainya dibawah 0,05 . Dengan demikian terdapat pengaruh yang signifikan antara variabel CSRI secara parsial terhadap Earning Response Coefficient (Y). Hasil uji t pada variabel Leverege $\left(\mathrm{X}_{2}\right)$ seperti pada tabel 5 diatas diperoleh t hitung sebesar 2,290 dengan probabilitas 0,027 yang nilainya dibawah 0,05 . Dengan demikian terdapat pengaruh yang signifikan antara variabel Leverage secara parsial terhadap Earning Response Coefficient (Y). Hasil uji t pada variabel Earning Response Coefficient (Y) seperti pada tabel 5 diatas diperoleh $\mathrm{t}$ hitung sebesar -9,762 dengan probabilitas 0,000 yang nilainya dibawah 0,05. Dengan demikian terdapat pengaruh yang signifikan antara variabel Good Corporate Governance (Z) secara parsial terhadap Earning Response Coefficient (ERC).

\section{Uji Signifikan Simultan (Uji Statistik F)}

Uji statistik F pada dasarnya menunjukan apakah semua variabel independen yang dimasukan dalam model mempunyai pengaruh secara bersama-sama terhadap variabel dependen (Ghozali, 2011).

Pengujian uji statistik F dilakukan dengan memperhatikan nilai:

1. Jika nilai sig $<0,05$ atau $\mathrm{F}$ hitung $>\mathrm{F}$ tabel maka terdapat pengaruh variabel $\mathrm{X}$ terhadap variabel $\mathrm{Y}$

2. Jika nilai sig $>0,05$ atau $\mathrm{F}$ hitung $<\mathrm{F}$ tabel tabel maka tidak terdapat pengaruh variabel $\mathrm{X}$ terhadap variabel $\mathrm{Y}$

Hasil uji simultan F dapat dilihat dari tabel 6 dibawah ini. 
Tabel 6

Hasil Uji Signifikansi Simultan

\begin{tabular}{lccccc}
\hline \multicolumn{5}{c}{ ANOVA $^{\mathbf{b}}$} \\
\hline Model & $\begin{array}{c}\text { Sum of } \\
\text { Squares }\end{array}$ & Df & $\begin{array}{c}\text { Mean } \\
\text { Square }\end{array}$ & F & Sig. \\
\hline $\mathbf{1} \quad \begin{array}{l}\text { Regressio } \\
\mathrm{n}\end{array}$ & .106 & 3 & .035 & 31.946 & $.000^{\mathrm{a}}$ \\
$\quad$ Residual & .049 & 44 & .001 & & \\
$\quad$ Total & .155 & 47 & & & \\
& & & & & \\
a. Predictors: (Constant), GCG, CSR, Leverage & & \\
b. Dependent Variable: \\
ERC
\end{tabular}

Sumber: Output SPSS 16.0, data sekunder yang diolah 2020

Berdasarkan tabel 6 di atas, di dapat $\mathrm{F}$ hitung sebesar 31,946 dengan probabilitas sebesar 0,000 yang nilainya dibawah 0,05 . Hal ini menunjukkan bahwa semua variabel independen yaitu CSRI, Leverage, dan Good Corporate Governance (GCG) berpengaruh signifikan secara simultan (bersama-sama) terhadap Earning Response Coefficient (ERC).

Ftabel $=(\mathrm{k} ; \mathrm{n}-\mathrm{k})$

$$
\begin{aligned}
& =(2 ; 46) \\
& =3,20
\end{aligned}
$$

Analisis Jalur (Path Analysis)

Pada tahap ini akan dihitung koefisien jalur model 1 dan koefisien jalur model 2, adapun penjelasannya sebagai berikut ini:

\section{Analisis Jalur Model 1}

Tabel 7

\section{Analisis Jalur Model I}

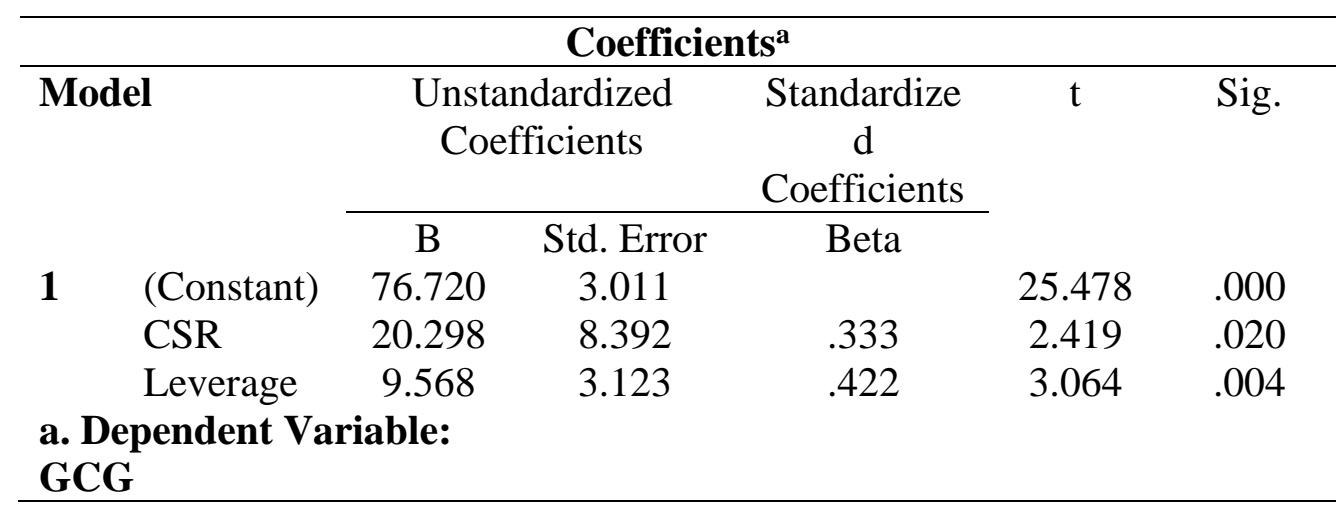

Sumber: Output SPSS 16.0, data sekunder yang diolah 2020

Mengacu pada output koefisien dapat diketahui bahwa nilai signifikansi dari dua variabel yaitu $\mathrm{X}_{1}=0,020$ lebih kecil dari 0,05 dan $\mathrm{X}_{2}=0,004$ lebih kecil dari 0,05. Hasil ini memberikan kesimpulan bahwa regresi model 1 yakni variabel $\mathrm{X}_{1}$ dan $\mathrm{X}_{2}$ berpengaruh terhadap variabel $\mathrm{Z}$. 
Tabel 8

Hasil R Square Model I

\begin{tabular}{lcccc}
\hline Model & Rodel Summary & R Square & $\begin{array}{c}\text { Adjusted R } \\
\text { Square }\end{array}$ & $\begin{array}{c}\text { Std. Error of } \\
\text { the Estimate }\end{array}$ \\
\hline $\mathbf{1}$ & $.460^{\mathrm{a}}$ & .211 & .176 & 3.82285
\end{tabular}

a. Predictors: (Constant), Leverage, CSR

Sumber: Output SPSS 16.0, data sekunder yang diolah 2020

Besarnya nilai $\mathrm{R}$ square yang terdapat pada tabel model summary adalah sebesar 0,211 hal ini menunjukkan bahwa pengaruh $\mathrm{X}_{1}$ dan $\mathrm{X}_{2}$ terhadap $\mathrm{Z}$ adalah $21,1 \%$ sementara sisanya $78,9 \%$ merupakan kontribusi dari variabel-variabel lain yang tidak dicantumkan dalam penelitian. Sementara itu, untuk nilai e1 dapat dicari dengan rumus e1 $=\sqrt{ }(1-0,211=0,888$ dengan demikian diperoleh diagram jalur model struktur 1 sebagai berikut:

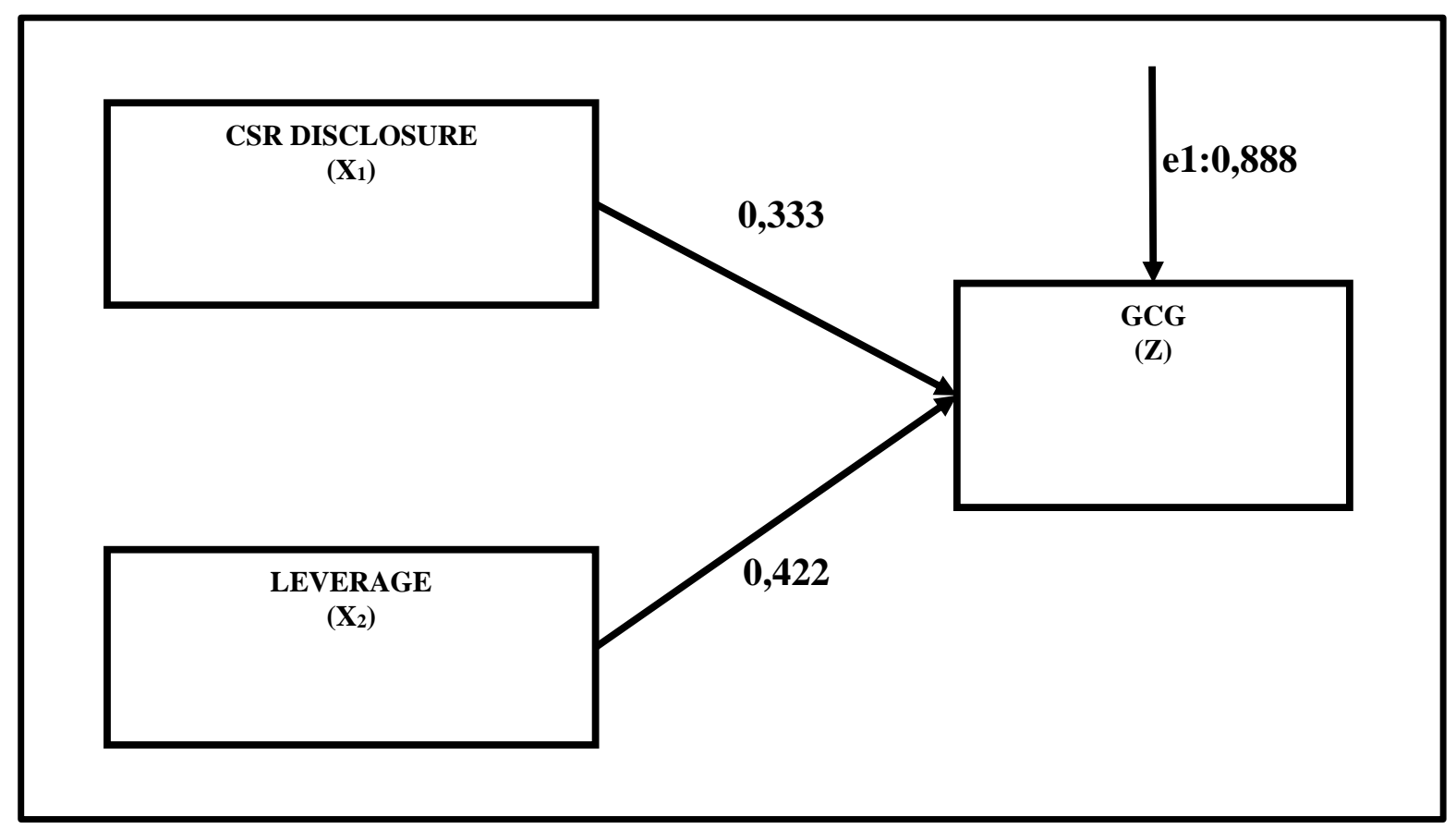

Bagan 1 Analisis Jalur Model 1 


\section{Buletin Ekonomi}

\section{Analisis Jalur Model 2}

Hasil analisis regresi jalur model 2 dapat dilihat pada tabel dibawah ini:

Tabel 9

Analisis Jalur Model II

\begin{tabular}{|c|c|c|c|c|c|c|}
\hline \multicolumn{7}{|c|}{ Coefficients $^{\mathbf{a}}$} \\
\hline \multirow[t]{2}{*}{ Model } & & $\begin{array}{r}\text { Unsta } \\
\text { Coe }\end{array}$ & $\begin{array}{l}\text { zed } \\
\text { ts }\end{array}$ & $\begin{array}{c}\text { Standardize } \\
\mathrm{d}\end{array}$ & $\mathrm{T}$ & Sig. \\
\hline & & B & $\begin{array}{l}\text { Std. } \\
\text { Error }\end{array}$ & Beta & & \\
\hline \multirow[t]{4}{*}{1} & (Constant & 1.900 & .078 & & 24.422 & .000 \\
\hline & CSR & 203 & .085 & .230 & 2.400 & .021 \\
\hline & Leverage & .069 & .030 & .223 & 2.290 & .027 \\
\hline & GCG & -.009 & .001 & -.863 & -9.762 & .000 \\
\hline
\end{tabular}

a. Dependent Variable: ERC

Sumber: Output SPSS 16.0, data sekunder yang diolah 2020

1. Berdasarkan output regresi model 2 pada bagian tabel koefisien diketahui bahwa nilai signifikansi dari tiga variabel yaitu $Z=0,000$ yaitu lebih kecil dari 0,05 . Hasil ini memberikan kesimpulan bahwa variabel $\mathrm{Z}$ berpengaruh terhadap variabel $\mathrm{Y}$.

2. Berdasarkan output regresi model 2 pada bagian tabel koefisien diketahui bahwa nilai signifikansi dari tiga variabel yaitu $X_{1}=0,021$ yaitu lebih kecil dari 0,05 . Hasil ini memberikan kesimpulan bahwa variabel $\mathrm{X}_{1}$ berpengaruh terhadap variabel $\mathrm{Y}$.

3. Berdasarkan output regresi model 2 pada bagian tabel koefisien diketahui bahwa nilai signifikansi dari tiga variabel yaitu $\mathrm{X}_{2}=0,027$ yaitu lebih kecil dari 0,05 . Hasil ini memberikan kesimpulan bahwa variabel $\mathrm{X}_{2}$ berpengaruh terhadap variabel $\mathrm{Y}$.

Tabel 4.10

Hasil R Square Model II

\begin{tabular}{ccccc}
\hline \multicolumn{4}{c}{ Model Summary } \\
\hline Model & $\mathrm{R}$ & $\mathrm{R}$ & $\begin{array}{c}\text { Adjusted R } \\
\text { Square }\end{array}$ & Std. Error of the Estimate \\
\hline 1 & $.828^{\mathrm{a}}$ & .685 & .664 & .033251
\end{tabular}

a. Predictors: (Constant), GCG, CSR, Leverage

Sumber: Output SPSS 16.0, data sekunder yang diolah 2020

Besarnya nilai $\mathrm{R}$ square yang terdapat pada tabel model summary sebesar 0,685 hal ini menunjukkan bahwa kontribusi $\mathrm{X}$ dan $\mathrm{Z}$ terhadap $\mathrm{Y}$ sebesar $68,5 \%$ sementara sisanya sebesar 31,5\% merupakan kontribusi dari variabel lain yang tidak diteliti. Sementara untuk nilai e2 dapat dicari dengan rumus e $2=\sqrt{ }(1-0,685=0,561$ dengan demikian diperoleh diagram jalur model sebagai berikut: 


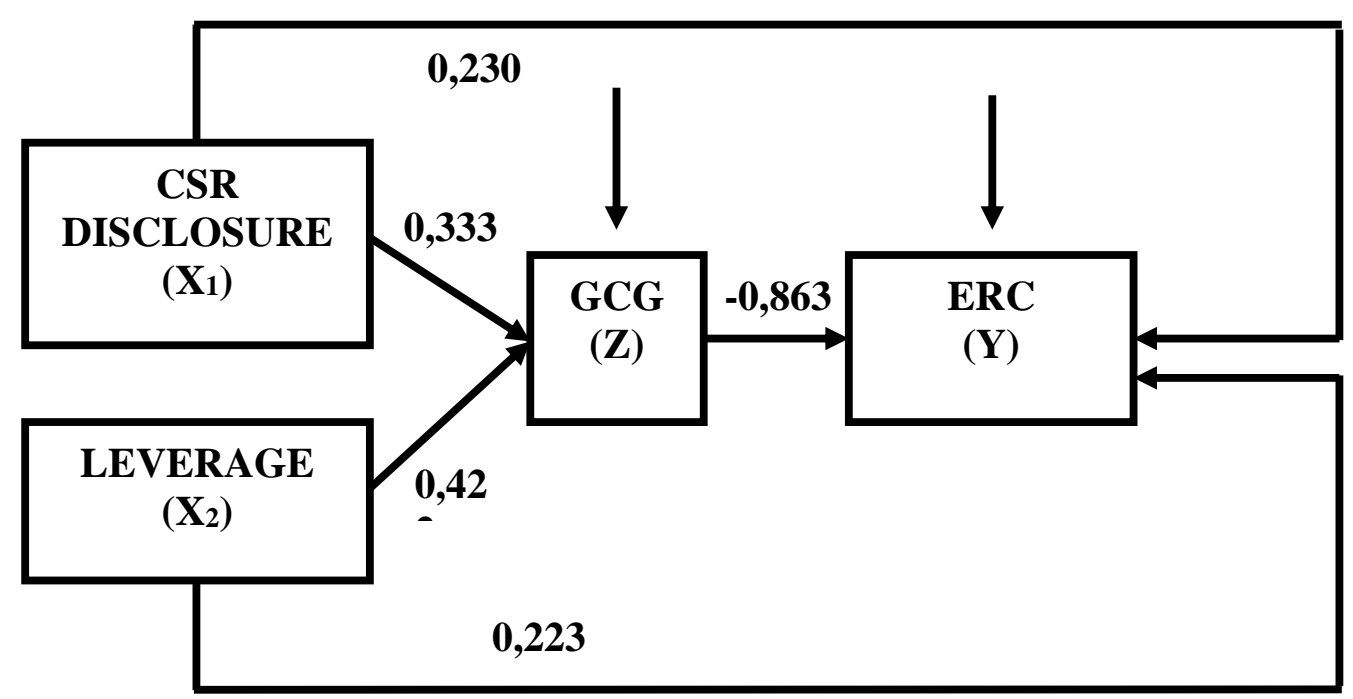

Bagan 2 Analisis Jalur Model 2

\section{Pengaruh Pengungkapan Corporate Social Responsibility positif terhadap Good Corporate Governance}

Hasil pengujian hipotesis ini dilakukan untuk membuktikan pengaruh pengungkapan corporate social responsibility terhadap good corporate governance yang dilakukan dengan pengujian regresi model 1 pada tabel 7 dapat dilihat bahwa variabel pengungkapan corporate social responsibility $\left(\mathrm{X}_{1}\right)=0,020$ lebih kecil dari 0,05 sehingga dapat disimpulkan bahwa variabel pengungkapan corporate social responsibility $\left(\mathrm{X}_{1}\right)$ berpengaruh positif terhadap good corporate governance (Z).

Pengungkapan corporate social responsibility berpengaruh terhadap good corporate governance karena dengan melakukan pengungkapan corporate social responsibility itu menandakan bahwa perusahaan memiliki kinerja sosial yang baik. Dimana pengungkapan CSR oleh perusahaan akan mendapat respon positif dan mendatangkan nilai yang baik bagi masyarakat. Jika perusahaan memiliki kinerja sosial yang baik maka penerapan konsep good corporate governance juga dapat dikatakan baik. Hasil penelitian tersebut didukung penelitian yang telah dilakukan oleh Ahmad Roziq (2017).

\section{Leverage berpengaruh negatif terhadap good corporate governance}

Hasil pengujian hipotesis ini dilakukan untuk membuktikan pengaruh leverage terhadap good corporate governance yang dilakukan dengan pengujian regresi model 1 pada tabel 7 dapat dilihat bahwa variabel leverage $\left(\mathrm{X}_{2}\right)=0,004$ lebih kecil dari 0,05 sehingga dapat disimpulkan bahwa variabel leverage $\left(\mathrm{X}_{2}\right)$ berpengaruh positif terhadap good corporate governance $(\mathrm{Z})$.

Leverage berpengaruh terhadap good corporate governance. Hal ini disebabkan bahwa semakin tinggi leverage menandakan adanya suatau tata kelola yang baik didalam perusahaan. Karena perusahaan melakukan pengendalian mengenai tata kelola yang sering disebut GCG. Hasil penelitian tersebut didukung penelitian yang telah dilakukan oleh Muhammad Akhyar Adnan,dkk (2016). 


\section{Buletin Ekonomi}

\section{Pengungkapan corporate social responsibility berpengaruh positif terhadap earning}

response coefficient

Hasil pengujian hipotesis ini di lakukan untuk membuktikan pengaruh pengungkapan CSR terhadap ERC yang dilakukan dengan pengujian regresi model 2. Pada tabel 9 dapat dilihat bahwa variabel pengungkapan CSR $\left(\mathrm{X}_{1}\right)=0,021$ lebih kecil dari 0,05. Hasil ini memberikan kesimpulan bahwa variabel pengungkapan corporate social responsibility $\left(\mathrm{X}_{1}\right)$ berpengaruh positif terhadap earning response coefficient (Y).

Pengungkapan corporate social responsibility berpengaruh terhadap earning response coefficient. Hal ini menunjukkan bahwa dengan melakukan pengumkapan CSR investor tidak hanya mengambil keputusan berdasarkan informasi laba saja. Namun investor akan memikirkan dan mempertimbangkan informasi CSR yang diungkapkan dalam laporan tahunan perusahaan. Hasil penelitian tersebut didukung penelitian yang telah dilakukan oleh Agung Prasetyo Nugroho Wicaksono (2017).

\section{Leverage berpengaruh negatif terhadap Earning Response Coefficient}

Hasil pengujian hipotesis ini di lakukan untuk membuktikan pengaruh pengungkapan CSR terhadap ERC yang dilakukan dengan pengujian regresi model 2. Pada tabel 9 dapat dilihat bahwa variabel pengungkapan CSR $\left(\mathrm{X}_{2}\right)=0,027$ lebih kecil dari 0,05. Hasil ini memberikan kesimpulan bahwa variabel pengungkapan corporate social responsibility $\left(\mathrm{X}_{2}\right)$ berpengaruh positif terhadap earning response coefficient $(\mathrm{Y})$.

Leverage berpengaruh terhadap earning response coefficient. Hal ini menunjukkan bahwa semakin tinggi hutang perusahaan, maka perusahaan tersebut akan semakin dinamis. Investasi yang meningkat digunakan sebagai sinyal untuk menunjukkan adanya prospek keuntungan dimasa mendatang. Hasil penelitian tersebut didukung penelitian yang telah dilakukan oleh Dira dan Astika (2016).

\section{Good Corporate Governance $(\mathrm{Z})$ berpengaruh positif terhadap Earning Response} Coefficient (Y)

Hasil pengujian hipotesis ini di lakukan untuk membuktikan pengaruh Good Corporate Governance terhadap earning response coefficient yang dilakukan dengan pengujian regresi model 2. Pada tabel 9 dapat dilihat bahwa variabel Good Corporate Governance (Z) nilai koefisien sebesar -9,762 dan signifikansi 0,000 lebih kecil dari 0,05. Hasil ini memberikan kesimpulan bahwa variabel pengungkapan Good Corporate Governance $(\mathrm{Z})$ berpengaruh negatif terhadap earning response coefficient $(\mathrm{Y})$.

Good Corporate Governance tidak berpengaruh terhadap earning response coefficient.Hal ini menunjukkan bahwa perusahaan dengan financial Leverage yang tinggi menghadapi default risk yang tinggi sehingga hasil saham dimasa mendatang akan lebih beresiko. Hasil penelitian tersebut didukung penelitian yang telah dilakukan oleh Putri Mutiara (2016).

Pengaruh pengungkapan Corporate Social Responsibility terhadap Earning Response Coefficient yang dimediasi Good Corporate Governance.

Hasil pengujian hipotesis ini dilakukan untuk membuktikan pengaruh pengungkapan corporate social responsibility terhadap earning response coefficient yang dimediasi good corporate governance Diketahui pengaruh langsung yang diberikan $\mathrm{X}_{1}$ terhadap $\mathrm{Z}$ sebesar 0,333 sedangan pengaruh tidak langsung $X_{1}$ terhadap $Y$ melalui $Z$ adalah perkalian nilai beta $\mathrm{X}_{1}$ terhadap $\mathrm{Y}$ dan nilai beta $\mathrm{Z}$ terhadap $\mathrm{Y}$ yaitu: $0,230 \times-0,863=-0,199$. Maka pengaruh total yang diberikan $\mathrm{X}_{1}$ terhadap $\mathrm{Y}$ adalah pengaruh langsung ditambah pengaruh tidak langsung yaitu: $0,333+(-0,199)=0,134$. Selain itu mediasi juga dapat dilihat dari perbandingan $t$ hitung dan $\mathrm{t}$ tabel, dimana $\mathrm{t}$ hitung $\mathrm{X}_{1}$ sebesar,2400 lebih besar dari t tabel yaitu sebesar 2,013. Hasil ini menunjukkan bahwa good corporate governance mampu memediasi pengungkapan corporate social responsibility terhadap earning response coefficient. 


\section{Buletin Ekonomi}

Menurut Nurika Restuningdiah (2016) menunjukkan bahwa Good Corporate Governance (GCG) mampu memediasi hubungan antara pengungkapan Corporate Social Responsibility (CSR) terhadap Earning Response Coefficient (ERC). Karena perusahaan semakin paham akan kewajibannya untuk perusahaan melaksanakan CSR dan mengungkapkannya dalam laporan tahunan. Dengan hal tersebut perusahaan bisa menciptakan tata kelola yang baik serta dapat membuat perusahaan menjalankan prinsip GCG secara sempurna.

Pengaruh Leverage terhadap Earning Response Coefficient yang dimediasi Good Corporate Governance

Hasil pengujian hipotesis ini dilakukan untuk membuktikan pengaruh pengungkapan corporate social responsibility terhadap earning response coefficient yang dimediasi good corporate governance Diketahui pengaruh langsung yang diberikan $\mathrm{X}_{2}$ terhadap $\mathrm{Z}$ sebesar 0,422 sedangan pengaruh tidak langsung $X_{2}$ terhadap $Y$ melalui $Z$ adalah perkalian nilai beta $\mathrm{X}_{2}$ terhadap $\mathrm{Y}$ dan nilai beta $\mathrm{Z}$ terhadap $\mathrm{Y}$ yaitu: $0,223 \mathrm{x}-0,863=-0,193$. Maka pengaruh total yang diberikan $\mathrm{X}_{1}$ terhadap $\mathrm{Y}$ adalah pengaruh langsung ditambah pengaruh tidak langsung yaitu: $0,422+(-0,193)=0,229$. Selain itu mediasi juga dapat dilihat dari perbandingan $t$ hitung dan $\mathrm{t}$ tabel, dimana $\mathrm{t}$ hitung $\mathrm{X}_{1}$ sebesar 2,290 lebih besar dari tabel yaitu sebesar 2,013. Hasil ini menunjukkan bahwa good corporate governance mampu memediasi leverage terhadap earning response coefficient.

Menurut Gemma (2017) menunjukkan bahwa Good Corporate Governance (GCG) mampu memediasi hubungan antara Leverage terhadap Earning Response Coefficient (ERC). Karena perusahaan yang memiliki komite audit dan berfungsi secara baik secara signifikan berpengaruh positif terhadap Leverage dan Earning Response Coefficient (ERC).

\section{KESIMPULAN}

Pada bagian akhir skripsi ini, penulis akan memaparkan beberapa kesimpulan yang dapat diambil dan saran yang didasarkan pada temuan hasil penelitian. Secara umum penulis menyimpulkan bahwa Good Corporate Governance (GCG) mampu memediasi hubungan antara Pengungkapan Corporate Social Responsibility (CSR) dan Leverage terhadap Earning Response Coefficient (ERC). Secara lebih khusus penulis dapat menarik kesimpulan yaitu sebagai berikut:

1. Pengungkapan Corporate Social Responsibility (CSR) berpengaruh positif dan signifikan terhadap Good Corporate Governance (GCG).

2. Leverage berpengaruh positif dan signifikan terhadap Good Corporate Governance (GCG).

3. Pengungkapan Corporate Social Responsibility (CSR) berpengaruh positif dan signifikan terhadap Earning Response Coefficient (ERC).

4. Leverage berpengaruh positif dan signifikan terhadap Earning Response Coefficient (ERC).

5. Good Corporate Governance (GCG) berpengaruh negatif dan signifikan terhadap Earning Response Coefficient (ERC).

6. Good Corporate Governance (GCG) mampu memediasi pengaruh pengungkapan Corporate Social Responsibility (CSR) terhadap Earning Response Coefficient (ERC).

7. Good Corporate Governance (GCG) mampu memediasi pengaruh Leverage terhadap Earning Response Coefficient (ERC). 


\section{Buletin Ekonomi}

\section{DAFTAR PUSTAKA}

Agung Prasetyo (2017). CSR Disclosure dan Earning Response Coefficient Universitas Airlangga Surabaya.

Anak Agung Puteri \& I Made Pande (2017). Pengaruh Leverage dan Ukuran Perusahaan Pada Earning Response Coefficient.

Ahmad Roziq (2017). Pengaruh Good Corporate Governance terhadap Corporate Social Responsibility melauli Risiko Bsinis dan Kinerja Keuangan.

Astika\&Dira (2016). Pengaruh Leverage dan Persistensi Laba terhadap Earning Response Coefficient.

Eric Tjandra (2016). Good Corporate Governance terhadap Leverage dan Profitabilitas.

Fenomena Earnings Response Coefficient (2017). Kasus BUMN Retrieved from https://finance.detik.com/bursa-dan-valas/d-3760208/laba-bumn-karya-naik-koksahamnya-terus-turun.

Gemma (2017). Pengaruh Profitabilitas, Leverage dan Good Corporate Governance (GCG) terhadap Earnings Response Coefficient.

Haris, Maikel (2017). Pengaruh Corporate Governance Index terhadap Earning Response Coefficient. Tesis Magister Akuntansi.

Intan Kurnia, Nur Diana, dan M. Cholid Mawardi (2017). Pengaruh Pengungkapan Corporate Social Responsibility, Good Corporate Governance, Ukuran Perusahaan Dan Profitabilitas terhadap Earning Response Coefficient.

Iskander dan Chamlou (2000). Corporate Governance: A Framwork For Implementasion. The International Bank For Reconstruction and Development. The World Bank.

Kadek Trisna \&I Gede (2017). Pengaruh Pengungkapan Corporate Social Responsibility Terhadap Earnings Response Coefficient (UNUD) Bali.

Kieso, D.E Weygant, J.J \& Warfield, T.D. (2007:2). Akuntansi Intermediate, Edisi 16. Jakarta: Erlangga.

Muhammad Akhyar Adnan, Barbara.G, dan Ratri.C (2016). Pengaruh Profitabilitas, Leverage, Growth, dan Fee Cash Flow terhadap Dividend Payout Ratio Perusahaan dengan Mempertimbangkan Corporate Governance sebagai Variabel Intervening.

Nurika Restuningdiah (2016). Mekanisme Good Corporate Governance dan Pengungkapan Tanggungjawab Sosial terhadap Koefisien Respon Laba.

Regiana,Diamonalisa\&Sri Fadilah (2017).Pengaruh Leverage, Ukuran Perusahaan dan Risiko Sistematis Terhadap Earning Response Coefficient Universitas Islam Bandung.

Riski Oktaviana.L (2016). Pengaruh pengungkapan Corporate Social Responsibility terhadap Earning Response Coefficient dengan Good Corporate Governance sebagai variabel mediasi.

Pradnyani, Ni Luh Putu.S.P, dkk (2016). Good Corporate Governance sebagai Prediktor Kinerja Keuangan dan Implikasinya pada Kebijakan Deviden. Jurnal Ekonomi dan Bisnis Universitas Udayana. Vol.02,No.08.

PSAK No.1 (Revisi 2009). Komponen Laporan Keuangan Lengkap, Penyajian Laporan Keuangan. 


\section{Buletin Ekonomi}

Puspita Ayu (2016). Pengaruh Good Corporate Governance terhadap Luas Pengungkapan Corporate Social Responsibility.

Putri Mutiara (2017). Pengaruh Corporate Governance dan Pengungkapan CSR terhadap ERC (perusahaan manufaktur tahun 2015)

Suwardjono (2005:491). Teori Akuntansi: Perekayasaan Pelaporan Keuangan. BPFE.

Suwardjono (2005:493). Teori Akuntansi: Perekayasaan Pelaporan Keuangan. BPFE.

Vinta, Yosefa \& Indah (2016). Pengaruh Pengungkapan Corporate Social Responsibility Terhadap Earnings Response Coefficient (Studi empiris pada perusahaan pertambangan yang terdaftar di BEI periode tahun 2010-2015).

Yusuf Wibisono (2007:35). Membedah Konsep dan Aplikasi Corporate Social Responsibility. Jakarta: PT Gramedia. 